\title{
FACTORS INFLUENCING THE EXTENT AND QUALITY OF CORPORATE SOCIAL RESPONSIBILITY DISCLOSURE IN INDONESIAN SHARI'AH COMPLIANT COMPANIES
}

\author{
Fedi Ameraldo* \\ Universitas Teknokrat Indonesia, Indonesia \\ Nazli Anum Mohd Ghazali \\ International Islamic University Malaysia, Malaysia
}

\begin{abstract}
This study aims to assess the extent and quality of corporate social responsibility (CSR) disclosure practices of Shari'ah Compliant Companies (ShCCs) in Indonesia. Further, the study examines the factors influencing the extent and quality of CSR disclosure of ShCCs in Indonesia. A checklist comprising of 33 items was constructed to measure the extent and quality of disclosure. Using data from the year 2014 annual reports of $100 \mathrm{ShCCs}$ in Indonesia, the results showed that the extent and quality of CSR disclosure among ShCCs in Indonesia were low with more than half of the sample companies scored less than $50 \%$ for extent of disclosure and all sample companies scored less than $50 \%$ for quality of disclosure. The multiple regression analysis revealed that award and leverage had an impact on the extent and quality of CSR disclosure. The findings indicate the need for improvement in the disclosure practice in annual reports of ShCCs. The relevant regulatory authority may issue guidelines and monitor companies' compliance to the guidelines to assist companies in enhancing CSR disclosure. Continuous and concerted efforts by the regulatory authority and ShCCs are necessary to ensure achievement of social transparency and accountability. This in turn may propel the development of Islamic capital market to the next level.
\end{abstract}

Keywords: Indonesia, CSR Disclosure, Shariah Compliant Companies, Awards.

Received: 10 June 2020

Accepted: 10 May 2021

https://doi.org/10.33736/ijbs.3775.2021

\section{INTRODUCTION}

In many countries, there is an increasingly apparent development of Islamic finance, especially the Islamic capital market (ICM) (Sadeghi, 2011). Muslim countries or countries with a Muslim majority have shown strong support to the development of the ICM (Alhabshi, 1994). This ICM development phenomenon is also evident in Indonesia with the release of fatwa No 40 which is related to Islamic capital market (DSN MUI, 2003). This fatwa allows the trading of Islamic financial instruments, such as Sukuk, Shari'ah-compliant mutual fund, stock, commercial paper, and other securities being traded in the capital market. Consequently, the release of fatwa became the starting point of ICM in Indonesia. While Islamic banks are established with specific principles

\footnotetext{
* Corresponding author: Department of Accounting, Faculty of Economics and Business, Universitas Teknokrat Indonesia, JL. ZA. Pagar Alam, Kota Bandar Lampung, Lampung 35132. E-mail : fediameraldo77@gmail.com
} 
that adhere to the Shari'ah regulations, Shari'ah Compliant Companies (ShCCs) have no specific regulations in complying with Shari'ah guidelines and principles, despite engaging in transactions that are still considered as shari'ah-compliant (Che Azmi et al., 2016). Thus, despite the ShCCs have been approved as companies which operate within accepted activities, they cannot be said to be similar to Islamic banks and other Islamic institutions because ShCCs were established in conventional setting rather than Islamic setting (Che Azmi et al., 2016). Additionally, Islamic financial institutions have a body within the institution to monitor and evaluate the business activities to ensure that the company does not engage in any prohibited activities. This special body, known as the Shari'ah Supervisory Board has been established in most Islamic banks but there is less in ShCCs compared to Islamic Banks (Al-Shammari, 2013).

The early stage of ICM in Indonesia started with the introduction of 164 ShCCs in 2007. ShCCs are perceived to be organizations that fulfill the perception and expectation of Muslim investors who have the intention to invest in ICM (Anuar et al., 2009). Hence, ShCCs are expected to disclose information related to the compliance of Islamic teaching in their annual reports (Haniffa, 2002; Maali et al., 2006). As argued by Anuar et al. (2009), ShCCs are also obligated to be more transparent compared to non-ShCCs. Haniffa (2002) highlighted that CSR disclosure should reflect the new and broader expectation of society. In this regard, Muslim investors, as a group within the society, have a high expectation towards ShCCs. Hence, ShCCs may need to disclose more information to meet investors' demand to fulfill both their economic and religious decisions (Haniffa \& Hudaib, 2002).

Unlike the conventional capital market which has been using the GRI guidelines as a benchmark to evaluate the practice of CSR disclosure (Bhimani \& Soonawalla, 2005), there is no standardization of disclosure policy which could satisfy the needs of Muslim investors and annual report users on Islamic principles and practices. For this particular concern, the department of ICM in the Indonesian Stock Exchange (IDX), ICM division of Indonesia Financial Services Authority (IFSA) and National Shari'ah Board play an important role for addressing this issue in order to further develop the growth of ICM in Indonesia. A guideline may be required to enhance the practices of social accountability and transparency in annual reports of ShCCs.

There are many prior studies on CSR disclosure. These studies were conducted in the contexts of developed (Branco \& Rodrigues, 2008; Gamerschlag et al., 2011; Krasodomska, 2015) and developing countries (Khan et al., 2013; Muttakin \& Subramaniam, 2015; Ratanajongkol et al., 2006; Siregar \& Bachtiar, 2010) with the majority of these studies on conventional listed companies. Meanwhile, numerous studies on Islamic institutions have focused on Islamic banks (Aribi \& Gao, 2012; Farook et al., 2011; Hassan \& Harahap, 2010). In contrast, a limited number of studies examining CSR disclosure practice of ShCCs (Anuar et al., 2009; Ousama \& Fatima, 2010b) had been carried out.

Since the ShCCs can be considered as Islamic institutions, the concept of social accountability and transparency need to be embedded in its corporate social reporting. Several prior studies (Baydoun \& Willet, 1997; Haniffa, 2002; Maali et al., 2006) have used the concept of social accountability and transparency as theories in order to explain how the Islamic institutions perform their reporting disclosure, particularly with items which should be disclosed in their annual reports. CSR disclosure practice of $S h C C s$ should differ from non-ShCCs because the objectives of ShCCs are different as compared to non-ShCCs (Haniffa, 2002). 
According to Haniffa (2002), CSR disclosure practice has two objectives. The first objective is to demonstrate accountability to God and community, and the second objective is to increase transparency of business activities by providing relevant information in conformance to the spiritual needs of Muslim decision makers. In order to reach the objective of accountability, the ShCCs should strive to provide lawful product and services as God's trustee (amanah), fulfill the obligation to God and society, be just to employees and community, and ensure the business activities are environmentally friendly. In addition, to achieve the objective of transparency, ShCCs should provide all information regarding all lawful and unlawful activities undertaken, financing and investment policy, employee policy, relationship with communities, the use of resources and protection of the environment. Thus, the objectives of CSR disclosure according to Haniffa (2002) can be summarized into five aspects which are finance and investment, products and services, employees, society and environment.

As indicated above, CSR disclosure studies have largely focused on non-ShCCs. On the other hand, Islamic banks have been widely studied compared to $S h C C s$. It is important to highlight that $S h C C s$ are perceived to be organizations that fulfill the perception and expectation of Muslim investors who have intention to invest in Islamic capital market (Anuar et al., 2009). Furthermore, according to Thijssens et al. (2015) secondary stakeholders such as community group, religious group and other non-governmental organizations (NGOs) may influence companies to satisfy their needs. This argument suggests that Muslim investors could also influence a company to show their accountability by disclosing the Islamic values and principles in its annual report. In addition, having a relevant public audience to which the organization is accountable to, is also important and crucial factors for companies to perform relevant and important disclosure. This means that in the context of ShCCs, having the relevant public audience such as Muslim population in Indonesia, may contribute to the level of social reporting disclosures. A study by Farook et al. (2011) revealed that $S h C C$ s in countries with a larger Muslim population had a higher level of CSR disclosure in their annual reports. In this regard, social reporting disclosure practice of ShCCs in a country with a large Muslim population is expected to be significant.

Recent studies on CSR in emerging including Muslim-majority countries generally report low level of disclosure. A study on firms listed on Tehran Stock Exchange between 2010 - 2015 reported that the average CSR disclosure was 23 percent (Salehi et al., 2019). A similar observation was documented in Indonesia where fully fledged Islamic Banks scored an average of 31 percent in CSR index (Nugraheni \& Khasanah, 2019). In another study by Saha (2019) on banks in Bangladesh, the average CSR disclosure score obtained was 2.86 (maximum possible of 4). Nevertheless, Islamic banks were found to report more CSR information than conventional banks. On the contrary, Alazzani et al. (2019) did not find significant difference in the extent of CSR disclosure between Shari'ah and non-Shari'ah compliant companies in Malaysia. Interestingly the study found companies with Muslim CEOs to have higher level of CSR disclosure, implying that religiosity of top management may have a positive influence on CSR disclosure. Elsewhere, an improved level of CSR disclosure was observed in commercial banks listed in the Kazakhstan Stock Exchange (KASE) for the period 2010- 2016, where the average improved from 29 percent in 2010 to 46 percent 2016 (Orazalin, 2019). The study also reported the significance of gender diversity on board in enhancing CSR disclosure. This positive influence of female directors on CSR disclosure was also observed in Pakistan (Khan et al., 2019). Majority of these studies were not examining Shari'ah compliant companies, hence an opportunity arises to analyse CSR disclosure practices in Shari'ah compliant companies. 
According to Schmith (2007), Indonesia with its large Muslim population is becoming a prospective financial market including Islamic based industry. With regards to this potential, Indonesia's development in the area of Islamic capital market should place high consideration on religious shareholders who put special attention to aspects regarding Sharia compliances. This is pertinent given that the number of $S h \mathrm{CC}$ has been in the increasing trend. The number of $S h \mathrm{CCs}$ have increased from 164 companies in 2007 to 322 companies in 2014 (IDX, 2014). This significant growth indicates the commitment of Indonesia to develop the Islamic capital market. In addition, the proportion of ShCCs are dominating public listed companies on the IDX accounting for almost $64 \%$ of total listed companies. Thus, the present study aims to assess the extent and quality of CSR disclosure and examine the factors influencing the extent and quality of CSR disclosure of ShCCs in Indonesia.

This study contributes to the literature on CSR disclosure studies in two ways. Firstly, this study provides empirical evidence on the extent and quality of CSR disclosure in Indonesian ShCCs, an area in which limited empirical evidence have been documented. Majority of prior studies on CSR have focused on the extent of disclosure in non-ShCCs and Islamic Banks. The present study extends prior studies by examining both the extent and quality of CSR disclosure in ShCCs. Indonesia provides an interesting avenue for investigation given that it is one of the top five most populous country. Indonesia also has the highest number of Muslims in the world. Accordingly, Indonesia's huge Muslim population can be expected to have some influence on the extent and quality of CSR disclosure. This is because the Muslim community places a high expectation towards the ShCCs and consequently, this should motivate the companies to differentiate their reporting practices including CSR disclosure from those non-ShCCs. Secondly, this study uses a self-constructed CSR disclosures index which includes Islamic aspects to examine the extent and quality of CSR disclosure in ShCCs' annual reports. In this regard, no past studies have examined CSR disclosure in ShCCs that particularly include the Islamic aspects in the disclosure checklist.

The remainder of the paper is structured as follows. Section 2 develops the theoretical framework and hypotheses of the study. Section 3 presents the research method employed whilst Section 4 presents the empirical results and discussion on the findings. Finally, Section 5 concludes the paper.

\section{THEORETICAL FRAMEWORK AND HYPOTHESIS DEVELOPMENT}

\subsection{Social Accountability and Transparency}

Islam has a foundation that is well-known as Tawhid(Unity). This concept means that there is only one God. As a Muslim, one should give full submission to Allah's will and resolution. A Muslim should practice the Islamic teachings according to the Al Quran and As Sunnah as guidance of life. Thus, each Muslim should behave accordingly and be responsible for all that he had done. Furthermore, every Muslim is a Khilafah (vicegerent) in the world. This implies that Muslims have responsibility not only for themselves, but also to the Ummah. As khilafah, Muslims are responsible for all resources given by Allah in the world and this trust has implication that Muslims should be accountable (Ikhtisab). Hence, as a Muslim, accountability is an important aspect in life as accountability to Allah also implies accountability to the society. 
The concept of social accountability is broad in Islam. Islam emphasizes that the rights of Allah is primary, followed by the rights of society. Hence, by considering the rights of Allah, Muslims should act and behave accordingly. Muslim should always ensure everything he or she does, including their deeds and words are complying with Islamic values. From this point of view, Muslims should maintain their good relationship with each other and the Islamic society as whole so that their rights are fulfilled. To fulfill these rights, Muslims will encourage themselves to be accountable for their actions, including to the society. According to Baydoun and Willet (1997), companies are accountable to the society for their actions, thus companies need to disclose the relevant information as one of the ways to discharge their accountability to the society.

In terms of disclosure, Islam recognizes the concept of transparency whereby companies inform the society about their activities and operations that could affect the society. Accordingly, transparency necessitates information disclosure (Maali et al., 2006). However, transparency here does not mean that all information should be disclosed but only those that are relevant and reliable. That is because disclosure of relevant and reliable information will help stakeholders to make not only economic related decisions, but also religious related decisions (Haniffa, 2002). For companies, information disclosure can be regarded as fulfilling their accountability to Allah and the society.

\subsection{Hypotheses Development}

The variables selected for analysis in this study are based on those which had been tested in conventional setting and has justifications based on Islamic perspectives. As this study aims to examine CSR disclosure in Islamic organizations, the ShCCs, two corporate governance variables (independent directors and female directors) and two corporate characteristics variables (industry and award) which are expected to contribute to ShCCs are chosen as independent variables. The hypotheses are developed in turn.

\subsubsection{Independent Directors}

Independent directors are appointed to provide a check and balance element in the board. Their appointment to corporate board should ensure that the board is independent from the influence of professional managers. Additionally, independent directors are supposed to monitor the actions of the executive directors and ensure that the interests of the minority shareholders are protected. Prior studies have revealed mixed results on the relationship between CSR disclosure and independent directors. While Ibrahim and Hanefah (2016) and Muttakin and Subramaniam (2015) documented significant positive relationship between the presence of independent directors and CSR disclosure in India and Jordan respectively, no significant relationship was observed in Indonesia (Handajani et al., 2014) and Malaysia (Ahmed Haji \& Mohd Ghazali, 2013).

In the case of ShCCs in Indonesia, a positive relationship is hypothesized based on the expectation that independent directors of ShCCs would act and serve in ways that ensure the $S h C C$ s operate within the Islamic principle. That is because $S h \mathrm{CCs}$ are recognized as Islamic institutions. It is also expected that an independent director plays the role of an outside director with an understanding of Islamic values, such as social accountability and transparency, which could enrich the content of CSR disclosure (Ahmed Haji, 2012). Thus, the presence of independent directors on board may 
have a positive impact on corporate social engagements which leads to enhanced CSR disclosure. Therefore, the following hypothesis is proposed,

Hypothesis 1: There is a significant positive relationship between independent directors and the extent and quality of CSR disclosure in annual reports of ShCCs.

\subsubsection{Female Directors}

In recent years, the issue of gender diversity on corporate board has emerged as one of the most researched aspect in corporate governance (Williams, 2003; Bear et al., 2010; Harjoto et al., 2015). Some countries have outlined the rulings on gender diversity to encourage more women to be in the top management of companies (Francoeur et al., 2008; Terjesen et al., 2009; Boulouta, 2013). The increased focus on women participation in the corporate sectors reflects the significance of gender equality issues in many developed countries.

Issues on gender diversity have also been examined in the context of CSR studies. A study in Indonesia by Handajani et al. (2014) showed that even though there was an increase in the number of females on the board, the increase has no effect on CSR disclosure. Similarly, Alazzani et al. (2019) also did not find women directors to be influencing CSR disclosure in Malaysia. The authors attributed the finding to the low number of female directors which is believed not sufficient to influence board's decisions. However, Bear et al. (2010) who examined the impact of number of women on board to CSR showed a positive relationship between the presence of women directors and CSR rating. This finding is consistent with Ibrahim and Hanefah (2016) and Khan et al. (2019) which reported the significance of female directors in improving CSR disclosure. These results indicate the importance of female directors in providing new perspectives and insights to the boardroom.

Women presence on the board may also have an impact on ethical decision by the board. Dawson in his study (1995) revealed that women tend to have more moral reasoning in all processes of decision making compared to men. Studies including Bateman and Valentine (2010), Ibrahim and Angelidis (2009), Lund (2008) observed females to be stricter than males when encountered with questionable situations. These findings suggest that appointing women to a company's top management could lessen the widespread issues on degradation of ethical standard in the business environment. This is pertinent to ShCCs because moral and ethical standards are the core aspects of ShCCs activities. ShCCs as religious based organizations, should emphasize on moral and ethical standards in all activities including their decision-making process. Thus, having women directors who are ethically inclined may contribute to higher level of CSR activities and disclosure, especially in ShCCs. Therefore, the following hypothesis is proposed,

Hypothesis 2: There is a significant positive relationship between women on board and the extent and quality of CSR disclosure in annual reports of ShCCs.

\subsubsection{Type of Industry}

Some industries may put higher level of attention to certain information due to various reasons (Mohd Ghazali, 2007). For instance, a manufacturing company may disclose more on employee issues while a chemical company may disclose more on issues related to the environment (Haniffa 
\& Cooke, 2005). However, companies that do not engage directly in manufacturing, such as multimedia and services companies, may have less concerns on environmental issues. Additionally, competitiveness has also be argued to be one of the reasons why industries face different degrees of pressure to disclose certain information (Mohd Ghazali, 2007). A high-profile industry may face a greater degree of competitiveness because of the attention given by stakeholders (Patten, 1991; Robert, 1992). However, Mirfazli (2008) found that there was no significance difference in the presentation of social disclosure among companies in various industries in Indonesia.

The pressures to disclose information experienced by companies described above may not apply to ShCCs. This is because promoting disclosure among ShCCs is a part of their accountability to all stakeholders without being motivated by competitiveness and other external pressures. Information disclosure is in line with the theory of social accountability and transparency. According to Islamic perspective, ShCCs may behave accordingly because they are responsible for all activities, not only to the society but ultimately to God. This sense of responsibility and accountability would encourage ShCCs to disclose relevant and important information to the stakeholders. In this light, the information provided can be used for stakeholders' decision making based on economic and religious aspects. Hence, there should not be any significant difference in information disclosure among different industries ShCCs. This leads to the following hypothesis,

\section{Hypothesis 3: There is no relationship between industry type and the extent and quality of CSR disclosure in annual reports of ShCCs.}

\subsubsection{Award}

Award is one of the variables that was less examined by prior studies. It has been reported some companies are motivated to disclose CSR information is to gain awards (Haniffa \& Cooke, 2005). Winning a CSR related award could also be part of a corporate strategy to legitimize its position in the society. Additionally, the award itself could be a reflection on a company's initiatives towards social and environmental issues. Firms which had received an award for good CSR practices have been found to have a higher level of CSR disclosure (Anas et al., 2015; Boesso \& Kumar, 2007).

Prior studies examining award has analyzed listed companies in general without focusing specifically on ShCCs (Anas et al., 2015; Boesso \& Kumar, 2007; Haniffa \& Cooke, 2005). It is perceived that award does not motivate ShCCs to disclose CSR information for the same reasons as other companies. Even though receiving an award for disclosing more CSR information could create a good image for the company, ShCCs are expected to disclose their CSR information with a different motivation. ShCCs may perceive awards differently as ShCCs perform disclosure as part of their commitment to present all the activities performed without exception to indicate their social accountability and transparency. That is because the $S h C C$ s have a special religious motivation that goes beyond receiving an award. However, receiving an award can be a testament of the good commitment of ShCCs to achieve social accountability and transparency. In other words, an award is not considered as a motivation, rather it can be used to signal that ShCCs are practicing social accountability and transparency. Thus, the following hypothesis is proposed, 
Hypothesis 4: There is a significant positive relationship between winning an award and the extent and quality of CSR disclosure in annual reports of ShCCs.

\subsubsection{Control Variables}

Based on prior research on CSR disclosure (Ahmed Haji, 2012; Hackston \& Milne, 1996) the present study selected three firm-specific variables, which are company size, profitability and leverage as control variables. Larger companies are more in the public eyes and therefore can be expected to engage in more social activities and disclosure of those activities. Engagements in social activities could also be part of a public image exercise. Hence, a positive relationship between company size and CSR disclosure is expected. Empirical evidence supporting this relationship includes Ahmed Haji (2013), Hackston and Milne (1996), Haniffa and Cooke (2005) and Mohd Ghazali (2007). In addition, companies which are more profitable can be expected to invest in more socially oriented activities because profitable companies could be expected to have the necessary resources for such investments. Profitability has been related found to be positively related to CSR disclosure (Haniffa \& Cooke, 2005; Mohd Ghazali \& Weetman, 2006). However, there have also been studies reporting that financial performance had no impact on CSR disclosure (Ahmed Haji, 2013; Ahmed Haji \& Mohd Ghazali, 2013). With regards to leverage, prior studies have documented mixed findings on the relationship with CSR disclosure. While Ahmed Haji (2013) did not observe leverage to be a significant variable influencing CSR disclosure, Ahmed Haji and Mohd Ghazali (2013) found a weak positive relationship between leverage and voluntary disclosure in ShCCs in Malaysia. In the present study a positive relationship between leverage and CSR disclosure is hypothesized. This is because ShCCs would use low leverage ratio (total debt to total assets) as a screening mechanism to determine whether the company is approved as a ShCC.

\section{METHODOLOGY}

\subsection{Research Design}

This research is a quantitative study examining factors influencing CSR disclosure in annual reports of ShCCs. Figure 1 depicts the variables included in the analysis.

Figure 1: Research Model

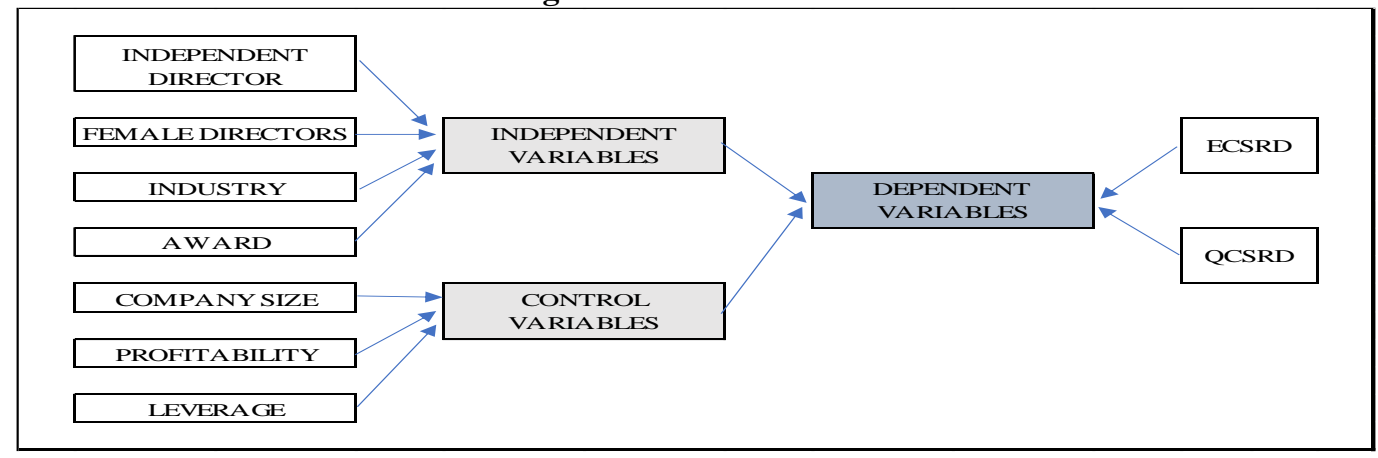




\subsection{Sample Selection and Data Collection}

The sample of this study comprises of ShCCs listed in Indonesia Shari'ah Stock Index (ISSI). The ShCCs account for almost 64\% of total listed companies (322 of 509 listed companies are ShCCs). ShCCs were identified from the 2014 Shari'ah index issued by Indonesian Financial Services Authority (FSA) and Indonesia Stock Exchange (IDX). ISSI announced the list of ShCCs twice a year. To ensure that the sample comprised of companies which were Shariah compliant throughout the year 2014, companies that were not listed twice in 2014 were eliminated. Of the total 322 ShCCs in 2014, the top $100 \mathrm{~S} h \mathrm{CCs}$ were chosen based on market capitalization due to several reasons. Firstly, large companies are more likely to disclose information voluntarily as they have more adequate resources compared to smaller companies. Secondly, large companies are perceived as the trend-setters and are therefore expected to establish good practices including social reporting. Selecting sample from large companies due to these reasons have been employed in prior disclosure studies (Ahmed Haji \& Mubaraq, 2015; Mohd Ghazali \& Weetman, 2006).

The data were collected from the annual reports of the selected companies for the year 2014. These annual reports are accessible through the companies' official website and the IDX website. Annual reports from 2014 were chosen because they were the most recent, complete and accessible for research at the start of this research. The use of annual report as the source of data is consistent with prior studies on corporate disclosure. Prior studies have suggested that annual reports are the primary method of communication between companies and stakeholders (Gray et al., 1995; Guthrie \& Parker, 1989).

\subsection{CSR Disclosure Index}

According to the Ousama and Fatima (2010b), developing a disclosure index based only on the Islamic perspective would not be possible in the initial stage of development, hence, the disclosure index includes the conventional perspective of social reporting that is developed from previous studies. The disclosure index is categorised in three parts - conventional, Islamic and general items. This study followed several steps in constructing the CSR disclosure index. Firstly, this study used CSR disclosure index prepared by Haniffa (2002) as a starting point for constructing disclosure index. Some adjustments were then made by referring to other studies in the same area of research such as Ahmed Haji and Mohd Ghazali (2013), Baydoun and Willet (2000), Maali et al. (2006), Nugraheni and Anuar (2014). Ousama and Fatima (2010b) and Sulaiman (2005). Secondly, the annual reports of companies which won the Indonesia Annual Report Award were used to gain additional information in constructing the disclosure index. Thirdly, the IDX listing requirement was checked to ensure that items in the disclosure index were voluntary in nature. Lastly, the disclosure index was given to certified Islamic capital market analysts to obtain their feedback for enriching and validating the content of the index.

This research employs the unweighted approach in measuring the extent of CSR disclosure (ECSRD) as one of the dependent variables. The formula for measuring ECSRD in the unweighted approach is as follow:

$$
\operatorname{ECSRD}=\sum_{i=1}^{n} d i
$$


Where $d$ scores 1 if the items $d_{i}$ is disclosed and 0 otherwise; and $n$ is the number of items which is expected to be disclosed by company $(n \leq 33)$. This approach of measuring the ECSRD based on the presence or absence of item is consistent with Ahmed Haji (2013), Esa and Mohd Ghazali (2012) and Said et al. (2018).

In contrast to ECSRD, the quality of CSR disclosure (QCSRD) uses a weighted approach with a three scoring value. If an item is not disclosed 0 will be awarded while a score of 1 is given if the item contains CSR information in qualitative form or in general terms. A score of 2 will be given if the item is disclosed with quantitative or monetary information. The highest score of 3 will be given if the item is disclosed with both qualitative and quantitative information. Prior studies (Ahmed Haji, 2012; Anas et al., 2015; Nugraheni \& Anuar, 2014) have used this weighted approach for measuring the quality of disclosure. The formula for QCSRD in weighted approach is as follows:

$$
Q C S R D=\frac{\mathrm{AS}}{\mathrm{TS}}
$$

Where QCSRD score was calculated as the ratio of actual scores (AS) awarded to a company to the total maximum disclosure scores (TS). The calculation for the AS for a company is calculated as follows:

$$
\mathrm{AS}=\sum_{i=1,2,3}^{n} d i
$$

Where $d$ scores 0 if the item $d_{i}$ is not disclosed, 1 if the item contains qualitative information or general terms, 2 if the item is disclosed with quantitative or monetary information and a score of 3 if the item is disclosed with both qualitative and quantitative information; and $n$ is the number of items which is expected to be disclosed by the company $(\mathrm{n} \leq 33)$. TS is computed by multiplying the maximum score of each item with the total items (i.e. $3 \times 33=99)$.

\subsection{Variable Measurement}

The measurement of dependent and independent variables is outlined in Table 1.

Table 1: Measurement of Variables

\begin{tabular}{lll}
\hline \hline Variable & Type & Operationalization \\
\hline ECSRD & Dependent & Score awarded (based on 1,0)/33 \\
QCSRD & Dependent & Score awarded (based on 0-3)/(33 x 3) \\
Independent Non-Executive & Independent & Number of INDs to total directors on board. \\
Director (IND) & & \\
Female on Board (Female) & Independent & Number of female directors to total directors on board. \\
Industry Type (IndType) & Independent & $0=$ non- manufacturing, 1 = manufacturing. \\
Award (Award) & Independent & $0=$ no award, 1 = award winner. \\
Company Size (Lsize) & Control & Log of total asset \\
Profitability (ROA) & Control & Profit/total asset \\
Leverage (Lev) & Control & Total debt/total asset \\
\hline \hline
\end{tabular}

The data for all variables were obtained from annual reports. 
The regression model for testing the hypotheses is as follows:

$$
\begin{aligned}
\text { ECSRD/QCSRD }= & \alpha+\beta 1 \text { IND }+\beta 2 \text { Female }+\beta 3 \text { IndType }+ \\
& \beta 4 \text { Award }+\beta 5 \text { Lsize }+\beta 6 \text { ROA }+\beta 7 \text { Lev }+e
\end{aligned}
$$

\section{RESULTS AND DISCUSSION}

\subsection{Descriptive Statistics}

\begin{tabular}{|c|c|c|}
\hline ECSRD (\%) & No. of Companies & $\%$ \\
\hline $1-9$ & 0 & $0 \%$ \\
\hline $10-19$ & 3 & $3 \%$ \\
\hline $20-29$ & 6 & $6 \%$ \\
\hline $30-39$ & 36 & $36 \%$ \\
\hline $40-49$ & 23 & $23 \%$ \\
\hline $50-59$ & 25 & $25 \%$ \\
\hline $60-69$ & 5 & $5 \%$ \\
\hline $70-79$ & 2 & $2 \%$ \\
\hline Total & 100 & $100 \%$ \\
\hline Minimum (\%) & & $12 \%$ \\
\hline Maximum (\%) & & $70 \%$ \\
\hline Mean $(\%)$ & & $43 \%$ \\
\hline $\mathrm{SD}$ & & 11.54 \\
\hline Kurtosis & & -0.20 \\
\hline Skewness & & -0.06 \\
\hline QCSRD (\%) & No. of Companies & $\%$ \\
\hline $1-9$ & 2 & $2 \%$ \\
\hline $10-19$ & 39 & $39 \%$ \\
\hline $20-29$ & 34 & $34 \%$ \\
\hline $30-39$ & 20 & $20 \%$ \\
\hline $40-49$ & 5 & $5 \%$ \\
\hline $50-59$ & 0 & $0 \%$ \\
\hline $60-69$ & 0 & $0 \%$ \\
\hline $70-79$ & 0 & $0 \%$ \\
\hline Total & 100 & $100 \%$ \\
\hline Minimum (\%) & & $4 \%$ \\
\hline Maximum (\%) & & $47 \%$ \\
\hline Mean (\%) & & $24 \%$ \\
\hline $\mathrm{SD}$ & & 8.89 \\
\hline Kurtosis & & -0.12 \\
\hline Skewness & & 0.61 \\
\hline
\end{tabular}

Table 2: Descriptive Statistics of ECSRD and QCSRD 
Table 2 above shows the extent and quality of the CSR disclosure in percentages for the 100 sample companies. 68 companies scored below 50\% in the extent of CSR disclosure where the other 32 companies scored $50 \%$ and above. Only 2 companies drew the highest score of $70 \%$ of ECSRD, while the minimum score was $12 \%$. Most of the companies scored between $30 \%$ to $39 \%$ in the ECSRD. The findings are acceptable as prior studies documented scores ranging from 0 to 19 (for a maximum possible score of 21) (Alazzani et al., 2019), an average of 30\% with scores ranging from 0 to $88 \%$ (Ibrahim \& Hanefah, 2016) and 9\% to 56\% (Nugraheni \& Khasanah, 2019).

Meanwhile in the quality of CSR disclosure, no company scored above $50 \%$. Most of the companies scored between $10 \%$ to $19 \%$. The lowest score for the QCSRD was $4 \%$ whereas the highest score was $47 \%$. These scores are comparable to prior studies as Ahmed Haji and Mohd Ghazali (2013) documented a range of $6.94 \%$ to $65.97 \%$ with an average of $20 \%$ while Nugraheni and Anuar (2014) reported a mean of 21.03 and range of 4 to 57 (maximum possible score of 90).

Table 2 also presents the skewness and kurtosis for ECSRD which are -0.06 and -0.20 respectively while that for QCSRD are 0.61 and -0.12 respectively. As the skewness are between -1.96 and +1.96 and the kurtosis are between -3 and +3 , these suggest that the scores are normally distributed (Gujarati, 2003, p. 147). Thus, parametric techniques such as multiple regression is considered appropriate for analysis.

Table 3: Descriptive Statistics of Continuous Variables

\begin{tabular}{lccccc}
\hline \hline & IND & Female & Lsize & ROA & LEV \\
\hline Min. & 0 & 0 & 20.81 & -0.16 & 0 \\
Max. & 0.8 & 0.75 & 38.99 & 0.54 & 0.83 \\
Mean & 0.4 & 0.08 & 29.8 & 0.08 & 0.39 \\
Std. Deviation & 0.12 & 0.15 & 2.33 & 0.08 & 0.18 \\
Skewness & 0.75 & 2.49 & 0.15 & 1.73 & 0.01 \\
Kurtosis & 2.19 & 7.25 & 7.14 & 10.17 & -0.27 \\
\hline \hline
\end{tabular}

Table 4: Descriptive Statistics of Dichotomous Variables

\begin{tabular}{ccc}
\hline \hline & & Frequency \\
\hline \multirow{2}{*}{ Industry type } & Non-manufacturing & 70 \\
& Manufacturing & 30 \\
\hline \multirow{2}{*}{ Award } & No award & 26 \\
& Award winner & 74 \\
\hline \hline
\end{tabular}

The results of the descriptive analysis of continuous independent variables are presented in Table 3. The variable Lsize has a mean score of 29.80 with minimum and maximum scores of 20.81 and 38.99 respectively. This natural logarithm can be used to solve the violation of normality assumptions (Anas et al., 2015). Other independent variables scored as low as zero for the minimum which means there are companies that do not have any independent directors, female director and leverage. Meanwhile, the ROA has a minimum score of -0.16 . Female director and ROA obtained the same lowest average score among these variables -0.08 . On the other hand, the 
average leverage is 0.39 . The maximum scores of IND and female are 0.80 and 0.75 suggesting that there are companies in which independent directors and female directors constitute more than half of the board.

Table 4 presents the frequency statistics of type of industry and award as dichotomous variables. The variable of industry type was divided into two categories, non-manufacturing and manufacturing industry. The table shows that of the 100 companies, $70 \%$ or 70 companies are nonmanufacturing companies, in contrast, 30 other companies fall into the manufacturing category. Meanwhile, the award variable represents the CSR-related awards obtained by companies. Table 4 also shows that 74 companies have obtained at least one CSR-related award, while 26 other companies have not received any awards.

\subsection{Reliability and Validity}

This study focuses on two reliability issues, the reliability of the instrument used and the reliability of the coded data i.e. the index scores. To address these two reliability issues, this study calculated the Cronbach's alpha, following Anas et al. (2015), for testing the reliability of the instrument used and a second coding process was conducted to ensure the reliability of the coded data.

Table 5: Reliability Statistics

\begin{tabular}{cccc}
\hline \hline ECSRD & \multicolumn{3}{c}{ QCSRD } \\
\hline Cronbach's Alpha & 0.668 & Cronbach's Alpha & 0.767 \\
No of Items & 33 & N0 of Items & 33 \\
\hline \hline
\end{tabular}

According to Norusis (2006) the Cronbach's alpha can be used to measure the internal validity and consistency of the items in the index. As shown in Table V, the Cronbach's alpha coefficient for all the 33 items of ECSRD and QCSRD are 0.668 and 0.767, respectively. Moss et al. (1998) suggest that Cronbach's alpha values of above 0.6 to be acceptable. This view is supported by Hair et al. (2006) who considers low Cronbach's alpha scores such as 0.6 in a small sample size study to be acceptable. Thus, based on these views and Cronbach's alpha scores observed, the instrument used in this study may be said to be internally consistent and reliable.

To ensure the reliability (producing consistent results if scored more than once or at different times) of the coded data i.e. the index scores, the coding was performed twice with an interval between the first and second-round coding. This method had been employed in prior studies (Ahmed Haji, 2013; Mohd Ghazali \& Weetman, 2006; Nugraheni \& Anuar, 2014). In the initial stage, the coder reviewed and familiarized the disclosure checklist before applying it to 20 annual reports. After being satisfied with the pilot-test process, coding and scoring were performed on all the 100 sample annual reports. Four weeks after the first coding, the annual reports were recoded to ensure no discrepancies in the scores. Comparison between the results of the first and second scoring revealed no significant difference. Therefore the coded data can be considered reliable. 


\subsection{The Extent and Quality of CSR Disclosure Practices}

Table 6: Themes of Disclosure

\begin{tabular}{|c|c|c|c|c|c|}
\hline \multicolumn{6}{|c|}{ ECSRD } \\
\hline & $\begin{array}{c}\text { No. of } \\
\text { Companies }\end{array}$ & Min. & Max. & Mean & $\begin{array}{c}\text { Std. } \\
\text { Deviation } \\
\end{array}$ \\
\hline $\begin{array}{l}\text { Finance and } \\
\text { Investment }\end{array}$ & 100 & 0 & 75 & 28.5 & 21.91 \\
\hline $\begin{array}{l}\text { Product and } \\
\text { Services }\end{array}$ & 100 & 0 & 100 & 44.3 & 19.42 \\
\hline Employee & 100 & 21 & 86 & 52.4 & 14.77 \\
\hline Society & 100 & 0 & 56 & 32 & 13.9 \\
\hline Environment & 100 & 0 & 100 & 59.5 & 29.89 \\
\hline \multicolumn{6}{|c|}{ QCSRD } \\
\hline & $\begin{array}{c}\text { No. of } \\
\text { Companies }\end{array}$ & Min. & Max. & Mean & $\begin{array}{c}\text { Std. } \\
\text { Deviation }\end{array}$ \\
\hline $\begin{array}{l}\text { Finance and } \\
\text { Investment }\end{array}$ & 100 & 0 & 42 & 10.6 & 9.32 \\
\hline $\begin{array}{l}\text { Product and } \\
\text { Services }\end{array}$ & 100 & 0 & 50 & 17.9 & 10.36 \\
\hline Employee & 100 & 7 & 64 & 30.6 & 12.01 \\
\hline Society & 100 & 0 & 48 & 19.1 & 11.43 \\
\hline Environment & 100 & 0 & 100 & 32.8 & 23.41 \\
\hline
\end{tabular}

Table 6 shows the minimum, maximum, mean, and standard deviation score in percentages based on themes for both ECSRD and QCSRD. It shows that the highest mean score was obtained by environment and employee theme for both ECSRD and QCSRD. In the context of ECSRD, environment theme shows the mean score of 59.50, followed by employee, product and services, society and finance and investment with 52.42, 44.25, 31.98 and 28.50, respectively. In the context of QCSRD, a similar pattern of disclosure occurs where environment theme is the highest score of mean (32.79), followed by employee (30.64), society (19.10), product and services (17.88) and finance and investment (10.60). In the context of ECSRD, product and services obtained the third highest mean score but in the context of QCSRD, society obtained the third highest mean score.

Table 6a: Islamic vs Conventional items

\begin{tabular}{lccccc}
\hline \hline \multicolumn{1}{c}{ Items } & Min & Max & Mean & Skewness & Kurtosis \\
\hline & \multicolumn{2}{c}{ ECSRD } & & & \\
\hline Islamic & 0.00 & 0.72 & 0.21 & 1.55 & 1.56 \\
Conventional & 0.13 & 0.99 & 0.58 & -0.28 & -1.41 \\
\hline \multicolumn{2}{c}{0.25} & 0.08 & 1.32 & 0.97 \\
\hline Islamic & 0.00 & 0.25 D & & 0.65 & -0.20 \\
Conventional & 0.06 & 0.80 & 0.34 & &
\end{tabular}

Descriptive statistics on the extent and quality of Islamic and conventional items disclosure is provided in Table 6a. The analysis shows that for both the extent and quality of CSR disclosure, 
the conventional items scored much higher than Islamic items. This is evident from the mean score of 0.58 for conventional ECSRD compared to 0.21 for Islamic ECSRD. Similarly, for QCSRD, conventional items averaged at 0.34 while Islamic items obtained a mean score of 0.08 . This finding is surprising given that ShCCs are expected to engage in more Islamic and Shari'ah compliant activities hence disclosure of those activities.

\subsection{Factors Influencing CSR Disclosure Practices}

\subsubsection{Correlation Results}

A correlation test was used for the purpose of finding whether there are correlations among independent variables. Based on the Pearson correlation coefficient results in Table 7, industry type is positively linked to ROA. The coefficient was at 0.258 with the significance level at $p<0.01$. This implies that manufacturing companies are likely to be more profitable than nonmanufacturing companies. Meanwhile, the Lsize variable has a significant correlation with award where it is positively associated with a coefficient of 0.198 and the significance level of $\mathrm{p}<0.05$. This indicates that larger companies are more likely to receive an award. ROA is shown to be significant and negatively associated with leverage at coefficient of -0.225 (significance level of $\mathrm{p}<0.05)$, which means that more profitable companies have lower leverage. Table 7 also shows that independent director has a significant positive correlation with ROA at coefficient level of 0.229 and significant at $5 \%$ which suggests that more profitable companies are more likely to have high number of independent directors. Other correlation coefficients which are not significant (i.e. at low values) indicate that the independent variables have no effect or not associated with one another.

Tabachnick and Fidell (2013) considers correlation coefficient of above 0.7 as harmful because it may lead to multicollinearity issues. High correlation among independent variables may imply that those variables may be a proxy for the same variable or factor. To address multicollinearity issues, Pallant (2016) suggests removing one of the highly correlated variables. As shown in Table, the correlation coefficients among the independent variables in this study are from -.225 (LEV and ROA) to .258 (ROA and Industry type). This shows that multicollinearity issues are not a problem in the research model.

Table 7: Pearson Correlations

\begin{tabular}{|c|c|c|c|c|c|c|c|}
\hline Variable & Award & Female & IND & $\begin{array}{r}\text { Industry } \\
\text { Type } \\
\end{array}$ & Lsize & ROA & LEV \\
\hline Award & 1 & & & & & & \\
\hline Female & .007 & 1 & & & & & \\
\hline IND & .013 & .052 & 1 & & & & \\
\hline $\begin{array}{l}\text { Industry } \\
\text { type }\end{array}$ & .139 & -.150 & .066 & 1 & & & \\
\hline Lsize & $.198 *$ & -.058 & -.011 & -.035 & 1 & & \\
\hline ROA & .018 & .032 & $.229 *$ & $.258 * *$ & -.167 & 1 & \\
\hline LEV & -.051 & .023 & -.056 & -.1060 & -.111 & $-.225^{*}$ & 1 \\
\hline
\end{tabular}

Notes: *p<0.05, **p<0.01 


\subsubsection{Regression Results}

Table 8: Multivariate Regression Analysis

\begin{tabular}{llllllll}
\hline \hline \multirow{2}{*}{ Variables } & \multicolumn{1}{l}{ ECSRD } & & \multicolumn{5}{c}{ QCSRD } \\
\cline { 2 - 8 } & $\begin{array}{l}\text { Standardized } \\
\text { Coefficients }\end{array}$ & $\mathrm{T}$ & $\begin{array}{l}\text { P- } \\
\text { value }\end{array}$ & $\begin{array}{l}\text { Standardized } \\
\text { Coefficients }\end{array}$ & $\mathrm{T}$ & $\begin{array}{l}\text { P- } \\
\text { value }\end{array}$ & $\mathrm{VIF}$ \\
\hline (Constant) & & 1.403 & 0.164 & & 0.294 & 0.769 & \\
IND & -0.095 & -0.981 & 0.329 & -0.138 & -1.431 & 0.156 & 1.059 \\
Female & -0.121 & -1.256 & 0.212 & -0.117 & -1.225 & 0.224 & 1.036 \\
Industry & 0.101 & 1.008 & 0.316 & 0.028 & 0.284 & 0.777 & 1.127 \\
type & 0.256 & $2.626^{*}$ & 0.010 & 0.259 & $2.670^{* *}$ & 0.009 & 1.067 \\
Award & 0.088 & 0.888 & 0.377 & 0.118 & 1.202 & 0.233 & 1.103 \\
Lsize & 0.195 & 1.867 & 0.065 & 0.19 & 1.834 & 0.070 & 1.223 \\
ROA & 0.243 & $2.479^{*}$ & 0.015 & 0.279 & $2.859^{* * *}$ & 0.005 & 1.083 \\
LEV & & $2.942^{* *}$ & & & $3.104^{* *}$ & & \\
F-value & & 0.183 & & & 0.191 & & \\
$\mathrm{R}^{2}$ & & & & & & & \\
\hline \hline
\end{tabular}

Notes: *p<0.05; **p<0.01

As shown in Table 8 above, the $R^{2}$ for the ECSRD is 0.183 with an $F$-value of 2.942 and significant at $1 \%$. The results show that there are two significant variables, which are award (significant at $1 \%$ ) and leverage (significant at 5\%). These findings suggest that companies which have won at least a CSR-related award and higher leveraged companies provide more ECSRD in annual reports. Turning to the regression on the QCSRD, the $R^{2}$ is 0.191 with $F$-value of 3.104 at $p=$ 0.001. Consistent with ECSRD, the results again show that award and leverage are significant variables, both at $1 \%$. The table also presents the variance inflation factor (VIF) values for the independent variables where there is no problem of multicollinearity, as all the VIF values are below five (De Vaus, 2002).

\subsection{Discussion of Findings}

\subsubsection{CSR Disclosure Practices}

The finding that ShCCs are more inclined to disclose environment information is consistent with Anuar et al. (2009) who found a similar result in the Malaysian context. Anas et al. (2015) also revealed that public listed companies (PLCs) in Malaysia tend to have more disclosure on environmental issues. The theme of employee which in this study is found to be the second most disclosed has also been documented in prior studies. For instance, Andrew et al. (1989), Nik Ahmad et al. (2003) and Teoh and Thong (1984), reported that the theme of employee or workplace are common theme disclosed by the PLCs in Malaysia.

The results also show that some items derived from Islamic values which are information on prohibited transaction/activities (Maysir, Gharar and Riba), Zakat, value-added statement or value added information and current value balance sheet (all in the finance and investment theme) are items with the lowest level of disclosure. 
This finding is surprising given $S h \mathrm{CC}$ are expected to practice high level of social accountability and transparency. This calls for further research on ShCCs to understand their motives for disclosure and non-disclosure. Engagements with practitioners may be one of the ways to unveil motivations for ShCCs' involvement in CSR activites and hence disclsoure.

In comparison to prior studies, the result of this study lends support to Ahmed Haji (2012) who revealed that the extent and quality of CSR disclosure in ShCCs are generally low and dominated by narrative disclosures. This indicates that from the Islamic perspective on the theory of social accountability and transparency, ShCCs are depending on the general business environment which affects the behavior of ShCCs in communicating their CSR activities (Ahmed Haji, 2012). Thus, ShCCs' CSR disclosure practices is far from expectation based on the theory of social accountability and transparency. This finding supports Che Azmi et al. (2016) who argued that ShCCs are not similar with Islamic banks. While Islamic banks are established based on principles that comply with the Shari'ah rules, in contrast, ShCCs do not specify themselves as institutions that implement Shari'ah guidelines and principles, even though, their activities are still considerably Shari'ah-compliant (Che Azmi et al., 2016). In addition, the Shari'ah advisory council has a low supervisory role in the Indonesian Islamic capital market which probably contributed to the low level of CSR disclosure by ShCCs.

\subsubsection{Factors Influencing CSR Disclosure Practices}

The results illustrate that award and leverage have a significant relationship with the extent and quality of CSR disclosure practice. Additionally, the industry type variable was not found to have a significant impact on the extent and quality of CSR disclosure. This finding supports the hypothesis that a relationship between the industry type and CSR disclosure does not exist.

The implication of the award variable is backed by previous studies by Anas et al. (2015) and Haniffa and Cooke (2005). Haniffa and Cooke (2005) opined that in disclosing CSR information, the management are usually motivated by awards. A company's image is believed to be enhanced through winning an award. Furthermore, Haniffa and Cooke (2005) also reasoned that the management's initiative to CSR issues can be indicated by the proxy of award. In short, winning an award equates to having good CSR policies including disclosure, as this is appreciated by stakeholders. In addition, with regards to $S h \mathrm{CC}$, winning awards due commendable CSR practices can also be viewed as fulfilling social accountability and transparency.

The variable of industry type was found to have no significant relationship with CSR disclosure, parallel to the studies by Anuar et al. (2009) and Ousama and Fatima (2010a). This suggests that regardless of the industry of the $S h C C$, the extent and quality of CSR disclosure is similar. This finding supports the Islamic perspective theory that emphasizes accountability to God and the society. Since ShCCs are responsible for all activities, regardless of their business activities whether in manufacturing or non-manufacturing the same principle of social accountability and transparency apply. Hence, relevant and important information should be provided by all ShCCs.

The significance of leverage in influencing CSR disclosure is inconsistent with the study by Ahmed Haji (2012), who argued that leverage could indicate less CSR practices since highly leveraged companies may find CSR activities to be unaffordable. This is due to the limitation of resources represented by high leverage. However, the hypothesis in the current research is developed from 
the observation of actual practices in the Indonesian Islamic capital market i.e. ShCCs were screened by limiting the ratio of leverage to never exceed 45 percent. The result indicates that within the allowable ratios of leverage, $S h C C$ s were still able to engage in good CSR practices. It appears that high leveraged ShCCs were able to manage their resources to meet dues while at the same time engaging in CSR activities and disclosure.

\section{CONCLUSION}

In terms of theme of CSR disclosure, the ShCCs had disclosed more information regarding the environment, followed by items related to the theme of employee. Surprisingly, items related to the Islamic value showed the least disclosure. Improvements are also required because no company scored more than $50 \%$ in the quality of disclosure, suggesting that sample companies disclosed qualitative rather than quantitative information. These findings indicate that guidance from the regulators is needed for the development of a more suitable and relevant CSR framework. To ensure social accountability and transparency, the regulator may require ShCCs to establish a Shari'ah Supervisory Board in each company. The Shari'ah Supervisory Board has been established by ShCCs in the Kuwaiti Islamic capital market. Such initiative can be undertaken by the Indonesian Islamic capital market as well. This governance system, which appoints Islamic scholars to be members of the Shari'ah Supervisory Board, has been generally practiced by Islamic banks. Implementing a similar governance system in ShCCs may promote the development of Islamic capital market to the next level.

The second research objective is to ascertain factors influencing the extent and quality of CSR disclosure. Two hypotheses could be accepted, namely the industry type and award. To date, previous studies showed that the variable of award had not been examined extensively in the context of ShCCs. The significance of this variable as evidenced in this study contributes to the literature by providing empirical evidence that award is an important factor determining CSR disclosure practices particularly in ShCCs.

This study contributes to the literature on CSR disclosure particularly in the Muslim world. As the number of CSR disclosure studies in ShCCs is lower as compared to studies regarding Islamic banks, this study fills the gap in the context of Islamic institutions, specifically in Indonesia. The study is relevant given Indonesia is a developing country with a majority Muslim population. The findings of this study show the extent of CSR disclosure is higher than the quality. This implies companies need to intensify their disclosure practices by providing more verifiable and informative disclosure. The results also show lack of disclosure of Islamic items. Based on this finding, the regulators and companies can take the necessary and appropriate steps to enhance CSR disclosure by ShCCs.

This study is not without limitations. Firstly, the study examined only one source of CSR disclosure which was the annual reports due to it being regarded as the main form of communication between a company and its stakeholders. Nonetheless a company may other channels such as press release and corporate website to communicate CSR information. Hence the scores obtained should be taken as a conclusive measure of a ShCC extent and quality of CSR disclosure. Secondly, the data were extracted from the annual reports of a single year. The use of the single year data may reflect the CSR practice of a particular year but does not measure the yearly trend of the disclosure. 
Thirdly, in terms of factors influencing CSR disclosure, the study only tested variables which are relevant in the context of ShCCs. Finally, the sample used in this study comprised of large companies hence, the result should not be generalized to all ShCCs population.

Future research may consider utilizing other sources such as press release, corporate-website or stand-alone CSR Report instead of relying on annual reports only. To obtain a more comprehensive result on the extent and quality of CSR disclosure in $S h C C$ s future study may include all $S h C C s$. Additionally, including the non-ShCCs in the analysis will enable a comparative study. By examining more companies of various sizes, the implications of the study can be fine-tuned and enhanced, due to a more eclectic sample. Finally, to improve the extent and quality of CSR disclosure practices by ShCCs, factors influencing should be comprehensively determined. This calls for research investigating a more diverse range of possible factors determining CSR disclosure.

\section{REFERENCES}

Ahmed Haji, A. (2012). The trend of CSR disclosures and the role of corporate governance attributes: the case of Shari'ah Compliant Companies in Malaysia. Issues in Social and Environmental Accounting, 6(3), 221-247.

Ahmed Haji, A. (2013). Corporate social responsibility disclosures over time: evidence from Malaysia. Managerial Auditing Journal, 28(7), 647-676.

Ahmed Haji, A., \& Mohd Ghazali, N. A. (2013). The quality and determinants of voluntary disclosures in annual reports of Shari'ah Compliant Companies in Malaysia. Humanomics, 29(1), 24-42.

Ahmed Haji, A., \& Mubaraq, S. (2015). The implication of the revised code of corporate governance on firm performance: a longitudinal examination of Malaysian listed companies. Journal of Accounting in Emerging Economies, 5(3), 350-380.

Alhabshi, S. O. (1994). Development of Capital Market under Islamic Perspective. Paper presented at the Conference on Managing \& Implementing Interest-Free Banking/Islamic Financial System, organised by Centre for Management Technology, supported by Bank Islam Malaysia Berhad, Concorde Hotel, Kuala Lumpur.

Alazzani, A., Wan-Hussin, W. N., \& Jones, M. (2019). Muslim CEO, women on boards and corporate responsibility reporting: some evidence from Malaysia. Journal of Islamic Accounting and Business Research, 10(2), 274-296.

Al-Shammari, B. (2013). An investigation of voluntary disclosure by Kuwaiti Shariah-Compliant Companies. Journal of Economic and Administrative Sciences, 29(1), 21-41.

Anas, A., Abdul Rashid, H. M., \& Annuar, H. A. (2015). The effect of award on CSR disclosures in annual reports of Malaysian PLCs. Social Responsibility Journal, 11(4), 831-852.

Andrew, B. H., Gul, F. A., Guthrie, J. E., \& Teoh, H. Y. (1989). A note on corporate social disclosure practices in developing countries: the case of Malaysia and Singapore. The British Accounting Review, 21, 371-376.

Anuar, H. A., Sulaiman, M., \& Nik Ahmad, N. N. (2009). Some evidence of environmental reporting: Shari'ah Compliant Companies in Malaysia. IIUM Journal of Economics and Management, 17(2), 177-208.

Aribi, Z. A., \& Gao, S. S. (2012). Narrative Disclosure of Corporate Social Responsibility in Islamic Financial Institutions. Managerial Auditing Journal, 27(2), 199-222. 
Bateman, C. R., \& Valentine, S. R. (2010). Investigating the effects of gender on consumers' moral philosophies and ethical intentions. Journal of Business Ethics, 95(3), 393 - 414.

Baydoun, N., \& Willet, R. (1997). Islam and accounting: ethical issues in the presentation of financial information corporate reports. Accounting, Comerce and Finance: The Islamic Perspective, 1(1), 1-24.

Baydoun, N. \& Willet, R. (2000). Islamic corporate reports. ABACUS, 36(1), 71-90.

Bear, S., Rahman, N., \& Post, C. (2010). The impact of board diversity and gender composition on corporate social responsibility and firm reputation. Journal of Business Ethics, 97(2), 207221.

Bhimani, A., \& Soonawalla, K. (2005). From conformance to performance: the corporate responsibility continuum. Journal of Accounting and Public Policy, 24(3), 165-174.

Boesso, G., \& Kumar K. (2007). Drivers of corporate voluntary disclosure: a framework and empirical evidence from Italy and the United States. Accounting, Auditing and Accountability Journal, 20(2), 269-296.

Boulouta, I. (2013). Hidden connections: the link between board gender diversity and corporate social performance. Journal of Business Ethics, 113(2), 85-197.

Branco, M. C., \& Rodrigues, L. L. (2008). Factors influencing social responsibility disclosure by Portuguese companies. Journal of Business Ethics, 83(4), 685-701.

Che Azmi, A. A., Ab Aziz, N., Non, N., \& Muhamad, R. (2016). Sharia disclosures: an exploratory study from the perspective of Sharia-Compliant Companies and Professional Users. Journal of Islamic Accounting and Business Research, 7(3), 237 - 252.

De Vaus, D. (2002). Survey in Social Research (5 ${ }^{\text {th }}$ Edition). Routledge. London

DSN MUI. (2003). Fatwa DSN-MUI No. 40/DSN-MUI/X/2003 Guidelines on Capital Markets and the General Principles of Islamic Capital Market. Jakarta.

Esa, E., \& Mohd Ghazali, N. A. (2012). Corporate social responsibility and corporate governance in Malaysian government-linked companies. Corporate Governance, 12(3), 292 - 305.

Farook, S., Hassan, M. K., \& Lanis, R. (2011). Determinants of corporate social responsibility disclosure: the case of Islamic banks. Journal of Islamic Accounting and Business Research, 2(2), 114-141.

Francoeur, C., Labelle, R., \& Sinclair-Desgagne, B. (2008). Gender diversity in corporate governance and top management. Journal of Business Ethics, 81(1), 83-95.

Gamerschlag, R., Möller, K., \& Verbeeten, F. (2011). Determinants of voluntary CSR disclosure: empirical evidence from Germany. Review of Managerial Science, 5(2-3), 233-262.

Gray, R. H., Kouhy, R., \& Lavers, S. (1995). Constructing a research database of social and environmental reporting by UK Companies: a methodological note. Accounting, Auditing \& Accountability Journal, 8(2), 78-101.

Gujarati, D. N. (2003), Basic Econometrics (4 ${ }^{\text {th }}$ ed.). New York: McGraw-Hill.

Guthrie, J., \& Parker, L. D. (1989). Corporate social reporting: a rebuttal of legitimacy theory", Accounting \& Business Research, 19(76), 343-352.

Hair, J., Black B., Babin B., Anderson R, \& Tatham R. (2006). Multivariate Data Analysis $\left(6^{\text {th }}\right.$ ed.). NJ: Pearson/Prentice Hall, Inc.

Hackston, D., \& Milne, M. J. (1996). Some determinants of social and environmental disclosures in New Zealand companies. Accounting, Auditing \& Accountability Journal, 9(1), 77-108.

Haniffa, R. (2002). Social reporting disclosure: an Islamic perspective. Indonesian Management \& Accounting Research, 1(2), 128-146.

Haniffa, R., \& Cooke, T. E. (2005). The impact of culture and governance on corporate social reporting. Journal of Accounting and Public Policy, 24(5), 391-430. 
Haniffa, R., \& Hudaib, M. A. (2002). A theoretical framework for the development of the Islamic perspective of accounting. Accounting, Commerce \& Finance: The Islamic Perspective Journal, 6(1/2), 1-71.

Handajani, L., Subroto, B., \& Saraswati, E. (2014). Does board diversity matter on corporate social disclosure? an Indonesian evidence. Journal of Economics and Sustainable Development, $5(9), 8-16$.

Harjoto, M., Laksmana, I., \& Lee, R. (2015). Board diversity and corporate social responsibility. Journal of Business Ethics, 132(4), 641-660.

Hassan, A., \& Harahap, S, S. 2010. Exploring corporate social responsibility disclosure: the case of Islamic banks. International journal of Islamic and Middle Eastern Finance and Management, 3(3), 203-227.

Ibrahim, N., \& Angelidis, J. (2009). The relative importance of ethics as a selection criterion for entry-level public accountants: Does gender make a difference? Journal of Business Ethics, 85(Supplement 1), $49-58$.

Ibrahim, A. H., \& Hanefah, M. M. (2016). Board diversity and corporate social responsibility in Jordan. Journal of Financial Reporting and Accounting, 14(2), 279-298.

Indonesia Stock Exchange. (IDX) (2014). Index Saham Syariah. Retrieved October 2, 2016 from https://www.idx.co.id/idx-syariah/indeks-saham-syariah/

Khan, A., Muttakin, M. B., \& Siddiqui, J. (2013). Corporate governance and corporate social responsibility disclosures: evidence from an emerging economy. Journal of Business Ethics, 114(2), 207-223.

Khan, I., Khan, I., \& Senturk, I. (2019). Board diversity and quality of CSR disclosure: evidence from Pakistan. Corporate Governance, 19(6), 1187-1203.

Lund, D. B. (2008). Gender differences in ethics judgment of marketing professionals in the United States. Journal of Business Ethics, 77(4), $501-515$.

Maali, B., Casson, P., \& Napier, C. (2006). Social reporting by Islamic banks. ABACUS, 42(2), 266-89.

Mirfazli, E. (2008). Corporate social responsibility information disclosure by annual reports of public companies listed at Indonesia Stock Exchange (IDX). International Journal of Islamic and Middle Eastern Finance and Management, 1(4), 275-284.

Mohd Ghazali, N. A. (2007). Ownership structure and corporate social responsibility disclosure: some Malaysian evidence. Corporate Governance: The international journal of business in society, 7(3), $251-266$.

Mohd Ghazali, N. A., \& Weetman, P. (2006). Perpetuating traditional influences: Voluntary disclosure in Malaysia following the economic crisis. Journal of International Accounting, Auditing and Taxation, 15(2), 226-248.

Moss, S. C., Prosser, H., \& Costello, H. (1998). Reliability and validity of the PAS-ADD checklist for detecting psychiatric disorders in adults with intellectual disability. Journal of Intellectual Disability Research, 42, 173-183.

Muttakin, M., \& Subramaniam, N. (2015). Firm ownership and board characteristics: do they matter for corporate social responsibility disclosure of Indian companies?. Sustainability Accounting, Management and Policy Journal, 6(2), 138-165.

Nik Ahmad, N. N., Sulaiman, M., \& Siswantoro, D. (2003). Corporate social responsibility disclosure in Malaysia: an analysis of annual reports of KLSE listed companies. IIUM Journal of Economics and Management, 11(1), 1-37.

Norusis, M. J. (2006). SPSS 15.0 Guide to data analysis. Chicago: SPSS. 
Nugraheni, P., \& Anuar, H. A. (2014). Implications of Shariah on the voluntary disclosure of Indonesian listed companies. Journal of Financial Reporting and Accounting, 12, 76-98.

Nugraheni, P., \& Khasanah, E. N. (2019). Implementation of the AAOIFI index on CSR disclosure in Indonesian Islamic banks. Journal of Financial Reporting and Accounting, 17(3), 365382.

Orazalin, N. (2019). Corporate governance and corporate social responsibility (CSR) disclosure in an emerging economy: evidence from commercial banks of Kazakhstan. Corporate Governance, 19(3), 490-507.

Ousama, A. A., \& Fatima, A. H. (2010a). Factors influencing voluntary disclosure: empirical evidence from Shariah Approved Companies. Malaysian Accounting Review, 9(1), 85-103.

Ousama, A. A., \& Fatima, A. H. (2010b). Voluntary disclosure by approved companies: an exploratory study. Journal of Financial Reporting and Accounting, 8, 35-49.

Pallant, J. (2016). Survival Manual (6 $6^{\text {th }}$ ed.). McGraw Hill, Berkshire UK.

Patten, D. M. (1991). Exposure, legitimacy and social disclosure. Journal of Accounting and Public Policy, 10(4), 297-308.

Ratanajongkol, S., Davey, H., \& Low, M. (2006). Corporate social reporting in Thailand: The news is all good and increasing. Qualitative Research in Accounting \& Management, 3(1), 67-83.

Robert, R. W. (1992). Determinant of Corporate Social Responsibility Disclosure: an Application of Stakeholder Theory. Accounting, Organization and Society, 17(6), 595-612.

Sadeghi, Mehdi. (2011). Shari'ah-Compliant investment and shareholders' value: an empirical investigation. Global Economy and Finance Journal, 4(1), 44-61.

Saha, A. K. (2019). Relationship between corporate social responsibility performance and disclosures: commercial banks of Bangladesh. Social Responsibility Journal, 15(4), 451468.

Said, R., Abd Samad, K., Mohd Sidek, N. Z., Ilias, N. F., \& Omar, N. (2018). Corporate social responsibility disclosure index of Malaysian Shariah - compliant companies. International Journal of Ethics and Systems, 34(1), 55-69.

Salehi, M., Tarighi, H., \& Rezanezhad, M. (2019). Empirical study on the effective factors of social responsibility disclosure of Iranian companies. Journal of Asian Business and Economic Studies, 26(1), 34-55.

Schmith, S. (2007). Islamic banking experiencing rapid growth. https://www. ita.doc.gov/td/finance/publications/IslamicBanking.pdf

Siregar, S. V., \& Bachtiar, Y. (2010). Corporate social reporting: empirical evidence from Indonesia Stock Exchange. International Journal of Islamic and Middle Eastern Finance and Management, 3, 241-252.

Sulaiman, M. (2005). Islamic Corporate Reporting: Between the Desirable and the Desired. Selangor, Malaysia: IIUM Research Centre.

Tabachnick, B. G., \& Fidell, L. S. (2013). Using Multivariate Statistics: International Edition. USA: Pearson.

Teoh, H. Y., \& Thong, G. (1984). Another look at corporate social responsibility and reporting: an empirical study in a developing country. Accounting, Organizations \& Society, 9(2), 189206.

Terjesen, S., Sealy, R., \& Singh, V. (2009). Women directors on corporate boards: a review and research agenda. Corporate Governance: An International Review, 17(3), 320-337.

Thijssens, T., Bollen, L., \& Hassink, H. (2015). Secondary stakeholder influence on CSR disclosure: An application of stakeholder salience theory. Journal of Business Ethics, 132(4), 873-891. 
Williams, R. J. (2003). Women on corporate boards of directors and their influence on corporate philanthropy. Journal of Business Ethics, 42(1), 1-10. 
Appendix 1: Corporate Social Reporting Disclosure Index

\begin{tabular}{|c|c|c|}
\hline THEME & ITEM & SOURCE OF REFERENCE \\
\hline $\begin{array}{l}\text { Finance and } \\
\text { Investment }\end{array}$ & $\begin{array}{l}\text { 1. Information on the } \\
\text { prohibited } \\
\text { transaction/activities } \\
\text { (Maysir, Ghara and Riba)* } \\
\text { 2. Zakat* } \\
\text { 3. Value-added statement or } \\
\text { value added information* } \\
\text { 4. Current Value balance } \\
\text { sheet* }\end{array}$ & $\begin{array}{l}\text { 1. Haniffa (2002), Sulaiman (2005), Ousama } \\
\text { and Fatima (2010a), Maali et al. (2006) } \\
\text { 2. Haniffa (2002), Sulaiman (2005), Ousama } \\
\text { and Fatima (2010a), Maali et al. (2006) } \\
\text { 3. Baydoun and Willet (2000), Ahmed Haji and } \\
\text { Mohd Ghazali (2013), Nugraheni and Anuar } \\
\text { (2014) } \\
\text { 4. Ousama and Fatima (2010a) }\end{array}$ \\
\hline $\begin{array}{l}\text { Products and } \\
\text { Services }\end{array}$ & $\begin{array}{l}\text { 5. Halal status of the product* } \\
\text { 6. Product safety and quality } \\
\text { 7. Responsiveness to customer } \\
\text { complains } \\
\text { 8. No involvement in non- } \\
\text { permissible activities } * *\end{array}$ & $\begin{array}{ll}\text { 5. Haniffa (2002), Sulaiman (2005), } & \\
\text { 6. Sulaiman (2005), Ousama and } \\
\text { Fatima(2010a), Ahmed Haji and Mohd } \\
\text { Ghazali (2013), Nugraheni and Anuar } \\
\text { (2014) } \\
\text { 7. Nugraheni and Anuar (2014) } \\
\text { 8. Haniffa and Hudaib (2007) }\end{array}$ \\
\hline Employee & $\begin{array}{l}\text { 9. } \begin{array}{l}\text { Nature of work: } * \\
\text { - working hours } \\
\text { - holidays }\end{array} \\
\text { 10. } \begin{array}{l}\text { Education and } \\
\text { training/Human } \\
\text { development }\end{array} \\
\text { 11. Number of employees } \\
\text { 12. Breakdown of employee by } \\
\text { education } \\
\text { 13. Breakdown of employee by } \\
\text { gender } \\
\text { 14. Breakdown of employee by } \\
\text { line of business department } \\
\text { 15. Recruitment policy } \\
\text { 16. Information on accident } \\
\text { 17. Equal opportunities ** } \\
\text { 18. Company's employees } \\
\text { pension plan } \\
\text { 19. Employee } \\
\text { reward/appreciation } \\
\text { 20. Employee welfare (Health } \\
\text { and Safety) } \\
\text { 21. Muslim employees are } \\
\text { allowed to perform their } \\
\text { obligatory prayers and } \\
\text { fasting on their working day } \\
*\end{array}$ & $\begin{array}{l}\text { 9. Haniffa (2002), Sulaiman (2005) } \\
\text { 10. Haniffa (2002), Sulaiman (2005), Ousama } \\
\text { and Fatima (2010a), Maali et al. (2006) } \\
\text { 11. Haniffa and Hudaib (2007) } \\
\text { 12. Ahmed Haji and Mohd Ghazali (2013), } \\
\text { Nugraheni and Anuar (2014) } \\
\text { 13. Ahmed Haji and Mohd Ghazali (2013), } \\
\text { Nugraheni and Anuar (2014) } \\
\text { 14. Nugraheni and Anuar (2014) } \\
\text { 15. Nugraheni and Anuar (2014) } \\
\text { 16. Ahmed Haji and Mohd Ghazali (2013), } \\
\text { Nugraheni and Anuar (2014) } \\
\text { 17. Haniffa (2002), Ousama and Fatima(2010a), } \\
\text { Maali et al. (2006) } \\
\text { 18. Nugraheni and Anuar (2014) } \\
\text { 19. Ahmed Haji and Mohd Ghazali (2013), } \\
\text { Nugraheni and Anuar (2014) } \\
\text { 20. Ousama and Fatima (2010a), Maali et al } \\
\text { (2006), Ahmed Haji and Mohd Ghazali } \\
\text { (2013), Nugraheni and Anuar (2014) } \\
\text { 21. Sulaiman (2005) } \\
\text { 22. Sulaiman (2005) }\end{array}$ \\
\hline Society & $\begin{array}{l}\text { 23. Charity ** } \\
\text { 24. Waqf * } \\
\text { 25. Qard Hassan /benevolent } \\
\text { loan } *\end{array}$ & $\begin{array}{l}\text { 23. Haniffa (2002), Sulaiman (2005), Baydoun } \\
\text { and Willet (2000), Ousama and Fatima } \\
\text { (2010a), Maali et al. (2006) } \\
\text { 24. Haniffa (2002) }\end{array}$ \\
\hline
\end{tabular}




\begin{tabular}{|c|c|c|}
\hline & 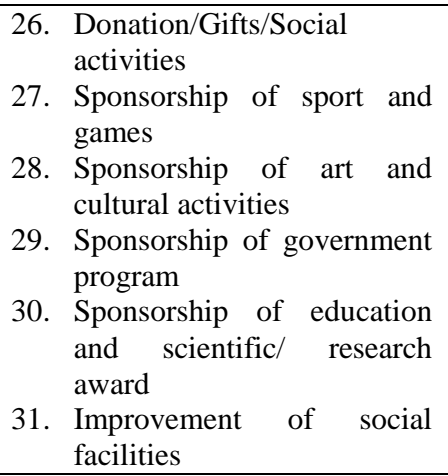 & $\begin{array}{l}\text { 25. Haniffa (2002), Ousama and Fatima } \\
\text { (2010a), Maali et al. (2006), Haniffa and } \\
\text { Hudaib (2007) } \\
\text { 26. Baydoun and Willet (2000), Ousama and } \\
\text { Fatima (2010b), Maali et al. (2006) } \\
\text { 27. Sulaiman (2005) } \\
\text { 28. Nugraheni and Anuar (2014) } \\
\text { 29. Nugraheni and Anuar (2014) } \\
\text { 30. Nugraheni and Anuar (2014) } \\
\text { 31. Nugraheni and Anuar (2014) }\end{array}$ \\
\hline Environment & $\begin{array}{l}\text { 32. Use of resources } \\
\text { 33. Pollution and environmental } \\
\text { protection program }\end{array}$ & $\begin{array}{l}\text { 32. Haniffa (2002) } \\
\text { 33. Haniffa (2002), Sulaiman (2005), Ahmed } \\
\text { Haji and Mohd Ghazali (2013), Nugraheni } \\
\text { and Anuar (2014) }\end{array}$ \\
\hline
\end{tabular}

(*) Islamic item

(**) considered as both Islamic and conventional item 